\author{
Kuprina N. \\ Ph.D., Associate Professor \\ E-mail: k.natali @ukr.net \\ Polish S. \\ Undergraduate \\ Department of Accounting and Auditing \\ Odessa National Academy of Food Technologies \\ Kanatna str., 112, Odessa, Ukraine, 65039 \\ E-mail: spyl09@bigmir.net
}

\title{
ESSENCE AND CLASSIFICATION OF SUPPLIES OF ENTERPRISE: THEORETICAL AND PRACTICAL ASPECT
}

In the article the analysis of modern approaches is conducted in relation to determination of essence of category "supplies" and their classification with the aim of further implementation of their effective administrative account. It's underlined, that enterprises of food industry of different patterns of ownership and types of activity are oriented on the use of different resources, from which supplies including productive are the important element of floating capital that needs their quality account and control, but in the literary sources and works of domestic and foreign scientists supplies are interpreted heterogeneously enough and need additional researches.

Keywords: supplies, productive supplies, classification, assets, $R(S) A$, products.

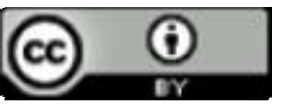

This work is licensed under a Creative Commons Attribution 4.0 International License http://creativecommons.org/licenses/by/4.0/

Statement of the problem and its connection with important scientific and practical tasks. For providing of trouble-free work of production and its effective activity on an enterprise there always must be productive supplies within the limits of the norms envisaged by the necessity of enterprise. In storage facilities enterprises the operation on maintenance of productive supplies are held that come, and also delivery them in production. The important condition of materials' account is the development of nomenclature of materials.

In every field of activity supplies are taken into account on legislatively determined methodology. As every type of supplies of activity has its methodology of accounting, they need to be examined separately one from another that is - productive, commercial or moneycredit and others like that. On enterprises every group of supplies can consist of hundreds and thousands of the names, sorts, sizes.

In production cost of enterprises of industry the part of charges of productive supplies presents about $50 \%$ but in food industry goes up to $80,0-85,0 \%$, that is why serious attention must be spared the questions of account, analysis and control, efficiency of the use of productive supplies, but it needs permanent improvement and searching for new methods. For the rational account of supplies that would assist operative management, planning and account, it is necessary to work out the detail grouping of supplies that is why it is important to research the approaches to determination of essence and classification of supplies.
The analysis of the latest publications on the problem.Research the concept of supplies, productive supplies, their classification, the question of accounting, analysis and audit are performed by the domestic and foreign authors, such as: I.Blanka, I..Bondareva, F.Butyntsya, V. Vasylenko, S.Golova, G. Davydova, E. Zin, T. Kacha, A. Kovalenko, T. Kolodyzeva, G. Kulabasova, L. Kulagovska, M. Kuhzilnyiy, R. Larina, G.Musa, V. Murashka, G. Nashkerska, L. Napadovska, Y. Picha, M. Pushkar, B. Rayzberg, Richard D.Invin, O. Solianyk, V. Sopka, N. Tkachenko, R.Z.Chase and others, but also nowadays is debatable.

Theoretical determination of essence, maintenance, role of supplies for providing the continuous work of production is very important for maintenance them on warehouses of enterprise where they always must be within the limits of the norms envisaged by the necessities of enterprise for implementation of trouble-free production of quality products.

Forming of the aims of the research. The aim of the article is research of determination of categories "Supplies" and "Productive supplies" for organization their administrative accounting and effective management certain element of floating capital of industrial enterprise.

Giving an account of the main results and their substantiation. Under productive supplies assets are understood that are used for consumption during the production of products, implementation of works 
and provision of services and also management the enterprise. Criteria of recognition of productive supplies of assets [12]:

- there is probability that enterprise will receive the economic values in the future related to their use;

- the cost of supplies can be determined for certain.

Accordingly, in default of confidence in relation to the receiving of economic values or application of unreliable estimation at admission and writing off materials authenticity of assets in balance causes doubts. At the same time it is necessary to provide exactness of data about supplies in financial statements [17].

Supplies are assets that are hold out for a sale; as productive supplies for consumption in the process of production of the prepared products, implementation of works and provision of services and also for management the enterprise [17].

Essence of concept "supplies" from different economic sources is driven to table 1 and approaches to their classification on the results of research are in table 2.

Table 1

Analysis of approaches to determination of essence of supplies and productive supplies*

\begin{tabular}{|c|c|}
\hline Author and source & Determination of essence of category \\
\hline $\begin{array}{l}\text { Regulations ( standard ) } \\
\text { of accounting } 9 \text { "Supplies" [13] }\end{array}$ & $\begin{array}{l}\text { Supplies are assets that: } \\
\text { are held out for a further sale at the terms of ordinary economic activity; are in the } \\
\text { process of production of the prepared products with the aim of further sale; } \\
\text { are held out for the necessities of management the enterprise. }\end{array}$ \\
\hline Sadovska I. [18, p.230 ] & $\begin{array}{l}\text { Supplies are assets that are held out for a sale; as productive supplies for consump- } \\
\text { tion in the process of production of the prepared products, implementation of } \\
\text { works and provision of services, and also for management the enterprise. }\end{array}$ \\
\hline Savkovych V. [17, p.8] & $\begin{array}{l}\text { Supplies is everything that demand is on but what is presently excluded from a } \\
\text { productive or personal consumption, they are all material, financial, labor and other } \\
\text { resources that are not used presently. }\end{array}$ \\
\hline $\begin{array}{l}\text { Posylkina O., } \\
\text { Sagaidak-Nikityuk R., } \\
\text { Dorovskiy O., } \\
\text { Kubasova G. [14, p. 254] }\end{array}$ & $\begin{array}{l}\text { Supplies are material resources that are on the different stages of production and } \\
\text { sale so that they are totality of raw materials, basic and auxiliary materials and oth- } \\
\text { er commodities that expect involving in the process of productive consumption or } \\
\text { prepared products that expect shipping to the consumer. }\end{array}$ \\
\hline Nashkerska G. [9, p.208] & $\begin{array}{l}\text { Supplies are circulating assets of enterprise that are used mainly in one operating } \\
\text { cycle of activity of enterprises or in a period up to one year. }\end{array}$ \\
\hline $\begin{array}{l}\text { Rayzberg B., Lozovskiy L., } \\
\text { Starodubtseva E. [ 16, p.113] }\end{array}$ & $\begin{array}{l}\text { Supplies are material values, current assets as raw materials, materials, fuel, ready- } \\
\text { to-cook foods, prepared products that are not used presently in a production that } \\
\text { are kept at warehouses or in other places and are intended for the next use. }\end{array}$ \\
\hline Gladkh T. [ 4] & $\begin{array}{l}\text { Supplies are assets that are held out for further sale at the terms of ordinary eco- } \\
\text { nomic activity; are in the process of production with the aim of further sale the } \\
\text { product of production; are held out for a consumption during the production of } \\
\text { products; implementation of works and provision of services, and also management } \\
\text { the enterprise. } \\
\text { Productive supplies are assets that are intended for the further processing on the } \\
\text { enterprise or are held out for another consumption during a normal operating cycle. }\end{array}$ \\
\hline $\begin{array}{l}\text { Kozlovskiy V., Kozlovska E., } \\
\text { Savrukov N. [7, p.95] }\end{array}$ & $\begin{array}{l}\text { A supply is any resource that is used in an order to satisfy a current or future neces- } \\
\text { sity (purveyances and pre-product, ready-to-cook foods that are in a productive } \\
\text { process and ready products). }\end{array}$ \\
\hline $\begin{array}{l}\text { Economic encyclopaedia } \\
{[5, \mathrm{p} .583]}\end{array}$ & $\begin{array}{l}\text { Supplies are the presence of corresponding material resources, which are capital } \\
\text { goods, articles of consumption, other values that are necessary for providing of the } \\
\text { extended recreation, maintenance of sphere of material production and satisfaction } \\
\text { of necessities of population and are not used yet. }\end{array}$ \\
\hline $\begin{array}{l}\text { Zhyvko Z. , Zhyvko M., } \\
\text { Zhyvko I. [6, p.121] }\end{array}$ & $\begin{array}{l}\text { Supplies are resources (assets) of enterprise that are kept for sale at the terms of } \\
\text { ordinary economic activity or are in the process of production for such sale or are } \\
\text { held out for consumption in a productive process or at provision of services, and } \\
\text { also for a management the enterprise (raw material and materials, stuff wares, pre- } \\
\text { pared products, fuel, building materials, commodities, less valuable and quickly } \\
\text { worn out objects and others like that). }\end{array}$ \\
\hline Bezinska R.. [1] & $\begin{array}{l}\text { Supplies are assets that: } \\
\text { 1) are held out for a further sale at the terms of ordinary economic activity; } \\
\text { 2) are in the process of production with the aim of further sale of product of pro- } \\
\text { duction; } \\
\text { 3) are held out for a consumption during the production of products and also for } \\
\text { management the enterprise. }\end{array}$ \\
\hline
\end{tabular}


Continue of table 1

\begin{tabular}{|c|l|}
\hline \multicolumn{1}{|c|}{ Author and source } & \multicolumn{1}{c|}{ Determination of essence of category } \\
\hline $\begin{array}{c}\text { Petlenko Y. [11, p.255], } \\
\text { Kuzhylnyiy M. [8, p.90] }\end{array}$ & Determination of supplies in accordance with R(S)A 9 \\
\hline Oglobin A. [10, p.31] & $\begin{array}{l}\text { Productive supplies are raw material, materials, purchased ready-to-cook foods } \\
\text { prepaid by a consumer that did not enter the productive process. }\end{array}$ \\
\hline Pushkar M. [15, p.74] & $\begin{array}{l}\text { Productive supplies are supplies of capital goods that are on warehouses of entity } \\
\text { and are needed for providing of continuous productive process, thus they are only } \\
\text { those articles of labor that are not involved in the process of production yet and } \\
\text { keep their naturally-material form. }\end{array}$ \\
\hline Sahantseva I. [19, p.163] & $\begin{array}{l}\text { Productive supplies (raw material, materials, fuel and others) that are the articles of } \\
\text { labor provide the productive process of enterprise with facilities of labor and labor } \\
\text { force where they are used once. }\end{array}$ \\
\hline $\begin{array}{l}\text { Butynets T., } \\
\text { Chyzhevska L., } \\
\text { Bereza S. [2, p.343] }\end{array}$ & $\begin{array}{l}\text { Productive supplies are assets that are used for a further sale, consumption during } \\
\text { the production of products, implementation of works and provision of services and } \\
\text { also management the enterprise. }\end{array}$ \\
\hline Butynets F. [3, p.313] & $\begin{array}{l}\text { Productive supplies are assets that are used for a further sale, use during the pro- } \\
\text { duction of products, implementation of works and provision of services and also } \\
\text { management the enterprise. }\end{array}$ \\
\hline
\end{tabular}

* it is made by the authors on the basis of analysis of sources

Table 2

Approaches to classification of supplies of enterprise*

\begin{tabular}{|c|c|c|}
\hline $\begin{array}{l}\text { Classification groups of } \\
\text { supplies }\end{array}$ & Type of supplies & Description \\
\hline \multirow{2}{*}{$\begin{array}{l}\text { 1. By purpose and by } \\
\text { reasons of formation }\end{array}$} & Permanent & $\begin{array}{l}\text { Part of productive supplies that provide continuity of productive } \\
\text { process between two regular deliveries }\end{array}$ \\
\hline & Seasonal & $\begin{array}{l}\text { Productive supplies that will appear at the seasonal production of } \\
\text { products or during the seasonal transporting }\end{array}$ \\
\hline \multirow{2}{*}{ 2. By location } & Warehousing & Productive supplies that are at warehouses of enterprise \\
\hline & In production & That are in the process of treatment \\
\hline \multirow[t]{2}{*}{$\begin{array}{l}\text { 3. By the level of pres- } \\
\text { ence on the enterprise }\end{array}$} & Normative & $\begin{array}{l}\text { Productive supplies that match the pre-arranged volumes of produc- } \\
\text { tive supplies necessary for providing of trouble-free work of enter- } \\
\text { prise }\end{array}$ \\
\hline & Overtime & That exceed their normative amount \\
\hline \multirow{2}{*}{ 4. Relatively to balance } & Balance & $\begin{array}{l}\text { Supplies that are property of enterprise and are represented in bal- } \\
\text { ance. }\end{array}$ \\
\hline & Off-balance & $\begin{array}{l}\text { Supplies that do not belong to the enterprise and are situated at it } \\
\text { for certain circumstances. }\end{array}$ \\
\hline \multirow{2}{*}{ 5. By origination } & Primary & $\begin{array}{l}\text { Supplies that came to an enterprise from other enterprises and are } \\
\text { not subjects of treatment }\end{array}$ \\
\hline & Secondary & $\begin{array}{l}\text { Materials and wares that can be used the second time in a produc- } \\
\text { tion }\end{array}$ \\
\hline \multirow{4}{*}{$\begin{array}{l}\text { 6. By composition } \\
\text { and structure }\end{array}$} & Productive supplies & $\begin{array}{l}\text { Supplies of raw material, basic and auxiliary materials, ready-to- } \\
\text { cook foods of own production, purchased ready-to-cook foods, stuff } \\
\text { wares, fuel, repair parts, container and packing-case materials, LQO }\end{array}$ \\
\hline & Supplies of WIP & $\begin{array}{l}\text { Part of products that did not pass all stages of treatment and was not } \\
\text { accepted by the department of technical control (DTC) }\end{array}$ \\
\hline & $\begin{array}{l}\text { Supplies of the pre- } \\
\text { pared products }\end{array}$ & $\begin{array}{l}\text { Products the production of which is completed that are accepted by } \\
\text { DTC and are at the warehouse }\end{array}$ \\
\hline & Commodity supplies & $\begin{array}{l}\text { Commodities that are in the field of turnover and also products that } \\
\text { are in transit. }\end{array}$ \\
\hline
\end{tabular}

*the generalized classification of types of supplies of enterprise by the authors is on founding [17] 
Methodological principles of forming the information about supplies and opening it in the financial reporting are regulated by Regulation (standard) of accounting (R(S) A) 9 "Supplies" [12]. The norms of this Regulation (standard) are used by enterprises, organizations and other legal entities regardless of patterns of ownership (except budgetary establishments) and do not spread on [12]:

- uncompleted works by building contracts, including contracts of provision of services that are directly related to them.

- financial assets.

- current biological assets, if they are estimated on a fair value in accordance with Regulation (standard) of accounting 30 "Biological assets" ratified by an order of Ministry of Finance of Ukraine from November 18, 2005 №790 and registered in Ministry of Justice of Ukraine on December 5, 2005 №1456/11736, minerals, if they are estimated on the net cost of realization in accordance with other regulations (standard) of accounting.

In $\mathrm{R}(\mathrm{S}) \mathrm{A} 9$ "Supplies" the following classification of supplies is brought [12]:

-raw materials, basic and auxiliary materials, stuff wares and other material values;
-WIP as not followed by treatment and stowage of details, knots, wares and technological processes; -prepared products that are made on an enterprise;

-commodities as material values;

-less valuable and quickly worn out objects;

-current biological assets.

Conclusions and prospects of the further investigations. Thus, research of issues of essence and classification of supplies allowed making a conclusion:

1. The analysis of publications sanctified to the accounting of the supplies of industrial enterprise allowed to give determination of essence of these economic categories, systematize their classification by corresponding signs, identify the issue of practical orientation for organization of accounting, administrative and tax recordkeeping of supplies of enterprise.

2. For the effective management of such element of floating capital as supplies it is necessary to research their state, motion, efficiency of the use on the enterprises of food industry, and also effective methods of management and control of them.

\section{References}

1. Bezinska, O. Bukhhalterskyi oblik. Retrieved May 11, 2017, from http://bookdn.com/book 268.html.

2. Butynets, T. A. (2001). Bukhhalterskyi oblik. Zhytomyr: PP "Ruta".

3. Butynets F. F. (2009). Bukhhalterskyi finansovyi oblik. Zhytomyr: PP "Ruta".

4. Hladkykh T.V. (2007).Finansovyi oblik. K. Tsentr navchalnoi literatury.

5. Mochernuy S.V. (2000). Ekonomichna entsyklopediia : u trokh t. K. Vydavnychyi tsentr «Akademiia».

6. Zhyvko Z.B., Zhyvko O.M., Zhyvko I.Iu. (2007). Slovnyk suchasnykh ekonomichnykh terminiv. Lviv:

Krai.

7. Kozlovskyi V.A., Kozlovskaia Э.A., Savrukov N.T. (1999). Lohystycheskyi menedzhment. SPb. Polytekhnyka.

8. M.V.Kuzhelnyi, V.H. Linnyk. (2001). Teoriia bukhhalterskoho obliku. K.KNEU.

9. Nashkerska H.V. (2004). Bukhhalterskyi oblik. K.Tsentr navchalnoi literatury.

10. Ohlobyn A.A. (1989). Planyrovanye y kontrol zapasov materyalnыkh resursov predpryiatyi v uslovyiakh novoi эkonomycheskoi reformb. Sverdlovsk.

11. Petlenko Iu.V. (2007). Finansovyi menedzhment. K. Kondor.

12. Polozhennia (standart) bukhhalterskoho obliku 9 «Zapasy» // Zatverdzheno Nakaz Ministerstva finansiv Ukrainy 20.10.99 №246 : stanom na 17 hrudnia 2012 r. Retrieved May 11, 2017, from http://zakon2.rada.gov.ua/ Kh. NFaU.

13. Posylkina O.V., Sahaidak-Nikitiuk R.V., Dorovskyi O.V. Kubasova H.V. (2009). Vyrobnycha lohistyka.

14. Pushkar M.S. Finansovyi oblik (2002). Ternopil. Kart-blansh.

15. Raizberh B.A., Lozovskyi L.Sh., Starodubtseva E.B. (1998). Sovremennыi эkonomycheskyi slovar. M. Ynfra.

16. Savkovych V.A. (1986). Modely upravlenyia zapasamy. Mn. Nauka y tekhnyka.

17. Sadovska I.B. (2013). Bukhhalterskyi oblik. K. Tsentr uchbovoi literatury.

18. Sakhartseva I. I.(2003). Osnovy skladannia bukhhalterskoi zvitnosti za vymohamy natsionalnykh standartiv Ukrainy. K. Kondor.

19. Blank Y. А. (2001). Fynansovыi menedzhment: uchebnыi kurs. K. Nyka-Tsentr, Эlha. 


\author{
Куприна Н.М. \\ кандидат экономических наук, доцент \\ кафедра учёта и аудита \\ E-mail:k.natali@ukr.net \\ Полиш C.B. \\ магистрант \\ кафедра учёта и аудита \\ Одесская национальная академия пищевых технологий \\ ул. Канатная, 112, г. Одеса, Украина, 65039 \\ E-mail: spyl09@bigmir.net
}

\title{
СУЩНОСТЬ И КЛАССИФИКАЦИЯ ЗАПАСОВ ПРЕДПРИЯТИЯ: ТЕОРЕТИЧЕСКИЙ И ПРАКТИЧЕСКИЙ АСПЕКТ
}

Целью статьи является исследование анализа публикаций ученых по определению сущности категорий «запасы» и «производственные запасы» для организации их управленческого учета и эффективного управления данным элементом оборотного капитала промышленного предприятия. В процессе исследования использовались методы: сравнительного анализа (для анализа подходов ученых к определению сущности категорий «запасы» и «производственные запасы»), метод классифрикации (для анализа классификации запасов предприятия по отдельным признакам с целью эффрективного управления и организации их учета).

Исследование понятия запасов, производственных запасов, их классификации, вопросов учета, анализа и аудита посвящены работы отечественных и зарубежных ученых, но и в настоящее время они являются дискуссионными. Проведенные исследования подтвердили, что для обеспечения бесперебойной работы предприятия и эффективной его деятельности на предприятии всегда должны быть производственные запасы в пределах норм, предусмотренных потребностью, а в к каждой сфере деятельности запасы учитываются по законодательно определенной методологии. Поскольку каждый вид запасов деятельности имеет свою методику учета, их нужно рассматривать отдельно друг от друга, поэтому теоретическое определение сущности, содержания, роли запасов необходимо для разработки эффективной политики управления ими для обеспечения функционирования предприятия, осуществления бесперебойного производства качественной продукции. В себестоимости продукции предприятий пищевой промышленности материальные затраты достигают 80,0-85,0\%, поэтому вопросам учета, анализа и контроля, эффективности их использования производственных запасов должно уделяться серьезное внимание, что требует постоянного совершенствования и поиска новых методов. Анализ публикаций, посвященных учету запасов на промышленном предприятии, позволил проанализировать подходы к определению сущности данных экономических категорий, систематизировать их классификацию по основным признакам, выявить вопросы практической направленности в качественной организации бухгалтерского, управленческого и налогового учета запасов предприятия.

Ключевые слова: запасы, производственные запасы, классификация, активы, П(С)БУ, продукция.

\author{
Купріна Н.М. \\ кандидат економічних наук, доцент \\ E-mail: k.natali @ukr.net \\ Поліш C.B. \\ магістрант \\ кафредра обліку та аудиту \\ Одеська національна академія харчових технологій \\ вул. Канатна, 112, г. Одеса, Україна, 65039 \\ E-mail: spyl09@bigmir.net
}

\section{СУТНІСТЬ ТА КЛАСИФІКАЦІЯ ЗАПАСІВ ПІДПРИЄМСТВА: ТЕОРЕТИЧНИЙ ТА ПРАКТИЧНИЙ АСПЕКТ}

Метою статті є дослідження аналізу праць вчених щодо визначення сутності категорій «запаси» та «виробничі запаси» для організації їх управлінського обліку та ефективного управління даним елементом оборотного капіталу промислового підприємства. В процесі дослідження використовува- 
лись методи: порівняльного аналізу (для аналізу підходів вчених до визначення сутності категорій «запаси» та «виробничі запаси»); метод класифікації (для аналізу класифікації запасів підприємства за окремими ознаками з метою ефективного управління та організації їх обліку).

Дослідження поняття запасів, виробничих запасів, їх класифікації, питанням обліку, аналізу та аудиту присвячені праці вітчизняних і зарубіжних вчених, але й на теперішній час вони є дискусійними. Проведене дослідженні підтвердило, що для забезпечення безперебійної роботи підприємства та ефективної його діяльності на підприємстві завжди мають бути виробничі запаси в межах норм, передбачених потребою, а у к кожній сфері діяльності запаси обліковуються за законодавчо визначеною методологією. Оскільки кожний вид запасів діяльності має свою методику обліку, їх потрібно розглядати окремо один від одного, тому теоретичне визначення сутності, змісту, ролі запасів необхідно для розробки ефективної політики управління ними для забезпечення функціонування підприємства, здійснення безперебійного виробництва якісної продукції. У собівартості продукції підприємств харчовій промисловості матеріальні витрати сягають 80,0-85,0\%, тому питанням обліку, аналізу та контролю, ефективності використання виробничих запасів має приділятися серйозна увага, але потребує постійного удосконалення та пошуку нових методів управління ними. Аналіз публікацій присвячених обліку запасів промислового підприємства дозволив визначити підходи щодо сутності даних економічних категорій, систематизувати їх класифікацію за відповідними ознаками, виявити питання практичної направленості в організації бухгалтерського, управлінського та податкового обліку запасів підприємства.

Ключові слова: запаси, виробничі запаси, класифікація, активи, П(С)БО, продукція.

\section{Література}

1. Безінська О. Бухгалтерський облік [Електронний ресурс]. - Режим доступу: http://bookdn.com/book 268.html.

2. Бутинець Т.А. Бухгалтерський облік: [навч. посіб.] / Бутинець Т.А., Чижевська Л.В., Береза С.Л.; за ред. проф. Ф.Ф. Бутинця. - Житомир: ПП “Рута”, 2001. - 576 с.

3. Бутинець Ф. Ф. Бухгалтерський фінансовий облік: [підруч. для студентів спеціальності «Облік і аудит» вищих навчальних закладів] / Ф.Ф. Бутинець. - Житомир: ПП «Рута», 2009. - 912 с.

4. Гладких Т.В. Фінансовий облік: [навч. посіб.] / Т.В. Гладких. - К.: Центр навчальної літератури, 2007. $-480 \mathrm{c}$.

5. Економічна енциклопедія : у трьох т. / [за ред. С.В. Мочерного]. - К.: Видавничий центр «Академія», - Т 1. - 2000. - 864 с.

6. Живко З.Б. Словник сучасних економічних термінів / Живко З.Б., Живко О.М., Живко І.Ю. - Львів: Край, 2007. - 384 с.

7. Козловский В.А. Логистический менеджмент / Козловский В.А., Козловская Э.А., Савруков Н.Т. СПб.: Политехника, 1999. - 275 с.

8. Кужельний М.В. Теорія бухгалтерського обліку: [підруч.] / М.В.Кужельний, В.Г. Лінник. - К.: КНЕУ, 2001. - 334 c.

9. Нашкерська Г.В. Бухгалтерський облік: [навч. посіб.] / Г.В. Нашкерська. - К. : Центр навчальної літератури, 2004. - 464 с.

10. Оглобин А. А. Планирование и контроль запасов материальных ресурсов предприятий в условиях новой экономической реформы : дис. канд. экон. наук : спец. 08.00.21 / А. А. Оглобин. - Свердловск, 1989. $243 \mathrm{c.}$

11. Петленко Ю.В. Фінансовий менеджмент: [навч. посіб.] / Ю.В. Петленко. - К.: Кондор, 2007. - 298с.

12. Положення (стандарт) бухгалтерського обліку 9 «Запаси» // Затверджено Наказ Міністерства фінансів України 20.10 .99 №246 : станом на 17 грудня 2012 р. [Електронний ресурс. - Режим доступу: http://zakon2.rada.gov.ua/.

13. Виробнича логістика: [навч. посіб. для студ. вищ. навч. закл.] / Посилкіна О.В., Сагайдак-Нікітюк Р.В., Доровський О.В., Кубасова Г.В. - Х.: НФаУ, 2009 - 364 с.

14. Пушкар М.С. Фінансовий облік: [підруч.] / М. С. Пушкар. - Тернопіль: Карт-бланш, 2002. - 626 с.

15. Райзберг Б.А. Современный экономический словарь / Райзберг Б.А., Лозовский Л.Ш., Стародубцева Е.Б. - [2-е изд. исправ]. - М. : Инфра, 1998. - 479 с.

16. Савкович В.А. Модели управления запасами / под ред. М.И. Балашевича. - Мн.: Наука и техника, 1986. - 319 c.

17. Садовська І.Б. Бухгалтерський облік: [навч. посіб. для вищої школи] / І.Б. Садовська. -К.: Центр учбової літератури, 2013. - $688 \mathrm{c}$.

18. Сахарцева I. I. Основи складання бухгалтерської звітності за вимогами національних стандартів України: [навч. посіб.] / I. І. Сахарцева. - К.: Кондор, 2003. - 614 с.

19. Бланк И. А. Финансовый менеджмент: учебный курс / И. А. Бланк. - К.: Ника-Центр, Эльга, 2001. $528 \mathrm{c}$. 